\title{
Original
}

\section{Alterations in Lipoprotein Composition Associated with Carbon Tetrachloride-Induced Rat Liver Injury}

\author{
Masahiro Inagaki, Sadao NaKayama and Katsuji Oguchi
}

\begin{abstract}
To investigate alterations in lipoprotein composition associated with carbon tetrachloride-induced rat liver injury, electrophoretic patterns of rat apoproteins were investigated by sodium dodecyl sulfate polyacrylamide gel electrophoresis (SDS-PAGE) and compared with those in man. Rat apoprotein (apo) A-I and apo E were shown to migrate the same distances as those of man, though rat apo A-II + apo C-II and apo C-III migrated farther. Administration of $1.0 \mathrm{ml} / \mathrm{kg} \mathrm{CCl}_{4}$ decreased the lipid contents, the very low density lipoprotein (VLDL), low density lipoprotein (LDL), and high density lipoprotein (HDL) fractions in the serum. Transaminase activity and total protein (TP) content increased with increased $\mathrm{CCl}_{1}$ administration. The percentage of albumin nonesterified fatty acid (Alb-NEFA) increased and $\mathrm{HDL}_{2}$ fraction decreased. Administration of $1.0 \mathrm{ml} / \mathrm{kg} \mathrm{CCl}{ }_{4}$ decreased apo $\mathrm{C}$-I and apo $\mathrm{E}$ in the $\mathrm{HDL}$ fraction. The bands of apo A-I, apo A-II, apo A-II + apo C-II and apo E in the $\mathrm{HDL}$ fraction declined after $2.0 \mathrm{ml} / \mathrm{kg} \mathrm{CCl}_{4}$ administration. Apoproteins in the VLDL + LDL fraction appeared to decrease after $\mathrm{CCl}_{4}$ treatment. It was suggested that lipoprotein abnormalities induced by $\mathrm{CCl}_{4}$ application may be related to inhibition of apoprotein synthesis, suppression of lipoprotein lipase activity, and the decline of $\mathrm{HDL}_{2}$.
\end{abstract}

Key words: apoproteins, lipoproteins, $\mathrm{CCl}_{4}$-induced liver injury, SDS-PAGE, rat

\section{Introduction}

Recent pharmacological studies of lipid metabolism have focused on determination of lipoprotein composition and apoprotein levels. Among many reports of lipoproteins, investigation of high density lipoprotein (HDL) seems to be of great interest, since HDL is a protective lipoprotein against premature development of atherosclerotic diseases. ${ }^{1,2)}$ Although lipoprotein fractions, such as very low density lipoprotein (VLDL), low density lipoprotein (LDL), and HDL are separated by ultracentrifugation or chemical procedures, apoprotein analysis is performed mainly by sodium dodecyl sulfate polyacrylamide gel electrophoresis (SDS-PAGE) or isoelectric focusing (IEF)., ${ }^{3,4)}$ Both the composition and function of apoproteins obtained from normal human serum have been studied.5, ${ }^{5)}$ It is also well known that various disease-induced hyperlipemia and liver diseases frequently develop abnormalities in lipid levels and lipoprotein compositions in human plasma or serum. ${ }^{7,8)}$ It is generally accepted that the composition and functions of human serum can be extrapolated from data obtained in experimental animals, yet few studies of lipoprotein and apoprotein patterns of 
normal and disease animal models have been available.9,10) Accumulating detailed data on apoproteins in animals is required to develop a disease model of human hepatic disorder. To do this we compared electrophoretic patterns of apoproteins in rat serum with those in human serum in the present study. In addition, changes in lipid levels and apoprotein patterns were examined in rats with liver injury induced by carbon tetrachloride $\left(\mathrm{CCl}_{4}\right)$. Such data could eventually lead to establishing an experimental animal model in which lipoprotein synthesis and metabolism can be studied in the light of updated lipid science.

\section{Materials and Methods}

Animals and reagents: Male, 8-week-old Sprague-Dawley rats weighing 250-280 g were used. Sodium chloride and sodium bromide were employed for lipoprotein separation. The chemicals used for lipoprotein analysis were as follows: hydrochloric acid, Tris-hydroxymethylaminoethane, $\mathrm{N}, \mathrm{N}, \mathrm{N}^{\prime}, \mathrm{N}^{\prime}$-tetramethylethylenediamine, acrylamide, $\mathrm{N}, \mathrm{N}^{\prime}$-methylene bisacrylamide, riboflavin, glycine, Sudan Black B. The chemicals used for apoprotein analysis by SDS-PAGE were as follows: acrylamide, sodium dodecyl sulfate, Tris-hydroxymethylaminoethane, $\mathbf{N}, \mathbf{N}, \mathbf{N}^{\prime}, \mathrm{N}^{\prime}$-tetramethylethylenediamine, ammonium persulfate, Coomassie Brilliant Blue $\mathrm{R}$, acetic acid, trichloroacetic acid, and methanol. Determinations of lipid, protein, and transaminase were carried out with commercial kits (Cholesterol B-Test, Phospholipid B-Test, Triglyceride G-Test, A/G B-Test, and Transaminase C II-Test were purchased from Wako Pure Chemical Industries Ltd., Japan, and BIO-RAD protein assay was obtained from BIO-RAD U.S.A.).

$\mathrm{CCl}_{4}$-induced liver injury: $\mathrm{CCl}_{4}$ was dissolved in olive oil, and its concentration was adjusted to $20 \%$ or $50 \%$. Three doses, $0.2,1.0$, and $2.0 \mathrm{ml} / \mathrm{kg}$ body weight, were given forcibly via stomach tube. The control animals were given olive oil alone at $2.0 \mathrm{ml} / \mathrm{kg}$ body weight. All animals were sacrificed $24 \mathrm{hr}$ after administration of the olive oil or $\mathrm{CCl}_{4}$.

Separation of lipoproteins: After fasting for $18 \mathrm{hr}$, animals were anesthetized with sodium pentobarbital $(40 \mathrm{mg} / \mathrm{kg}$, i.p.). Subsequently, the abdomen was opened, and 5 to $6 \mathrm{ml}$ of blood was collected from the inferior vena cava with a disposable syringe. Serum was separated by centrifugation at 2.500 r.p.m. for $15 \mathrm{~min}$. Lipoprotein fractions were obtained from the serum of 2 animals by ultracentrifugation with a HIMAC ultracentrifuge (Hitachi, Japan) using an RP-40 rotor; for the isolation of VLDL and LDL fraction $(\mathrm{d}<1.063 \mathrm{~g} / \mathrm{ml})$, serum was overlaid with a $\mathrm{NaCl}$ solution $(\mathrm{d}=1.21 \mathrm{~g} / \mathrm{ml}$, containing $95.4 \mathrm{mg} / \mathrm{ml} \mathrm{NaCl}$ and 197 $\mathrm{mg} / \mathrm{ml} \mathrm{NaBr}$ ) at a volume ratio of 1:6.4 (saline solution to serum). Centrifugation was then carried out at $105,000 \times \mathrm{g}$ for $22 \mathrm{hr}$. The upper lipoprotein layer of $3.5 \mathrm{ml}$ was used as the VLDL+LDL fraction, and $3.5 \mathrm{ml}$ of the bottom fraction was used as the HDL fraction.

Separation of apoproteins: The VLDL+LDL fraction and HDL fraction were dialyzed for $24 \mathrm{hr}$ with saline containing $0.05 \% \quad \mathrm{Na}_{2}$ EDTA. Aproproteins were isolated by delipidation using ethanol/diethyl ether (3:1 for VLDL+LDL, 3:2 for HDL) and anhydrous diethyl ether at $0^{\circ} \mathrm{C}$, and the products were dried under $\mathrm{N}_{2}$ gas flow.

Lipoproteins and albumin nonesterified fatty acids (Alb-NEFA) electrophoresis: Serum liproproteins were assayed by the prestaining disk PAGE method. ${ }^{11}$ Serum was stained with saturated-Sudan Black B for $20 \mathrm{hr}$. Three layers of acrylamide were piled; acrylamide concentrations were $1.875 \%$ for the stacking gel and $3 \%$ and $5 \%$ for the running gels. Prestained serum $(100 \mu \mathrm{l})$ was added onto the stacking gel. Electrophoresis was carried out with Tris/glycine buffer $(0.05 \mathrm{mM}, \mathrm{pH} 8.4)$ at $1.5 \mathrm{~mA} /$ disk, 
Apoprotein electrophoresis: SDS-PAGE of apoproteins was carried out according to a modified method of Weber and Osborn. ${ }^{12)}$ The concentrations of acrylamide were $7 \%$ for the stacking gel and $12 \%$ for the running gel. Two $\mathrm{mg}$ of apoprotein was dissolved in 500 $\mu \mathrm{l}$ of $0.5 \mathrm{M}$ Tris $/ \mathrm{HCl}$ (pH 6.8, containing $1 \% \mathrm{SDS}$ ), $0.002 \%$ bromophenol blue, and $6 \%$ sucrose. This solution $(25 \mu \mathrm{l})$ was added onto the stacking gel. Monomeric, dimeric, trimeric, tetrameric, and hexameric forms of cytochrome c were mixed ( $5 \mu \mathrm{l}$ each, $25 \mu \mathrm{l}$ total volume) and introduced into a hole as a molecular weight marker for migration. Electrophoresis was carried out with Tris/glycine buffer $(0.05 \mathrm{M} / 0.28 \mathrm{M}, \mathrm{pH} 8.3)$ containing $0.1 \%$ SDS at a current of $5 \mathrm{~mA}$ followed by $30 \mathrm{~mA}$. Subsequently, the gel was fixed for $2 \mathrm{hr}$ with $10 \%$ tricholoroacetic acid and $25 \%$ methanol at room temperature, then stained for $2 \mathrm{hr}$ with a solution containing $0.05 \%$ Coomassie Brilliant Blue R, $10 \%$ acetic acid and $10 \%$ methanol, followed by overnight destaining with $10 \%$ methanol and $10 \%$ acetic acid. Apoprotein bands were identified by comparing with the mobilities of the reference proteins and rat HDL apoproteins whose molecular weights were already known. ${ }^{3.13)}$

Densitometry: The densities of lipoprotein and apoprotein bands were measured with a densitometer (F-808, Cosmo Co. Ltd., Japan).

Analysis of lipid, protein, and enzyme: Chemical analysis of serum and lipoprotein fractions was performed as follows: total cholesterol (TC) was determined by the colorimetric method; ${ }^{14)}$ phospholipid (PL) and triglyceride (TG), by the enzymatic method; ${ }^{15,16)}$ activity of transaminase (GOT, GPT) in serum, by the colorimetric method; ${ }^{17)}$ total protein (TP) in serum, by the method for Buret; ${ }^{18)}$ and protein in lipoprotein fractions, by the method of Bradford. ${ }^{19)}$

Statistical analysis: Statistical significance was evaluated using Student's $t$-test. A p-value of less than 0.05 was considered statistically significant.

\section{Results}

1. Comparison of electrophoretic patterns of apoproteins in HDL fraction derived from human and rat

Stained bands of apo A-I, apo A-II + apo C-II, apo C-I, and apo E obtained from rat HDL were separated by SDS-PAGE. Apo A-I and apo E in rat HDL fraction migrated the same distances as those of man (Fig. 1). The migrations of apo A-II+apo C-II and apo C-I of rats were slightly farther of those of human. Since the amounts of apo A-II + C-II and apo C-I in rat samples were very small, it was difficult to recognize the bands in the left-most column which was produced from an application of $25 \mu \mathrm{l}$ of rat sample. For confirmation, electrophoresis was repeated with an application of $100 \mu \mathrm{l}$ of the rat sample; the result of which is shown in the second column from the left. The position of all rat apoprotein bands was faintly but positively recognizable on the photograph. In quantitative densitometrical measurement, only electrophoretic results obtained with applications of $25 \mu \mathrm{l}$ of the sample were compared. Stained bands of human apoproteins in Fig. 1 were not clear.

2. $\mathrm{CCl}_{4}$-induced liver injury in rats

Changes in serum transaminase: GOT and GPT levels in serum were increased significantly by $\mathrm{CCl}_{1}$ administrations at 1.0 and $2.0 \mathrm{ml} / \mathrm{kg}$. Administration of $\mathrm{CCl}_{1}$ at $0.2 \mathrm{ml} / \mathrm{kg}$ caused no change in transaminase levels (Table 1).

Changes in lipids and proteins in serum and lipoprotein fractions: Serum TC content was significantly decreased by $\mathrm{CCl}_{1}$ administration at $1.0 \mathrm{ml} / \mathrm{kg}$, mainly due to the decline of TC 


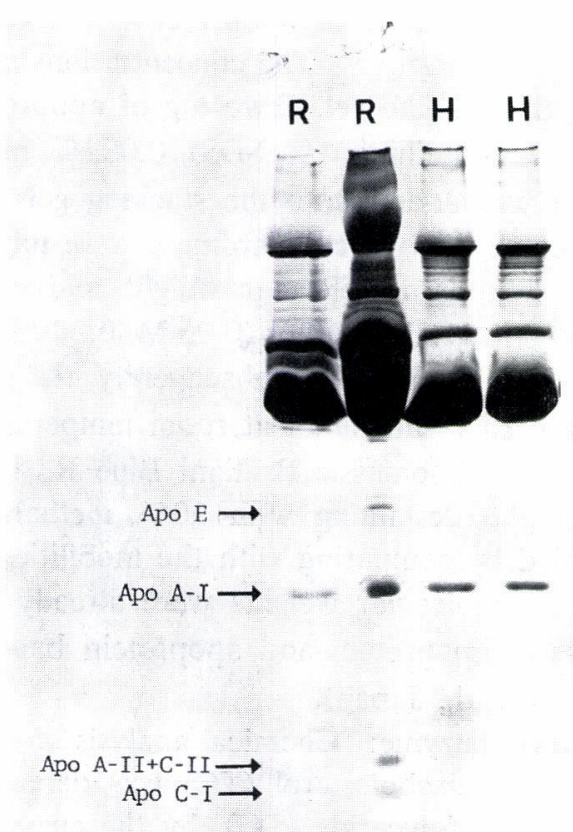

Fig. 1. Sodium dodecyl sulfate polyacrylamide gel electrophoresis (SDS-PAGE) patterns of apoproteins in high density lipoprotein (HDL) obtained from rats and humans. $\mathrm{R}$ : rat, H: human. SDS-PAGE was conducted with application of $25 \mu 1$ of sample except for the second column from the left, in which $100 \mu \mathrm{l}$ of the rat sample was applied.

Table 1. Changes in transaminase activity, serum lipid and protein levels in $\mathrm{CCl}_{4}$-liver-damage rats.

\begin{tabular}{|c|c|c|c|c|c|}
\hline & & \multirow{2}{*}{ Control } & \multicolumn{3}{|c|}{ Doses of $\mathrm{CCl}_{4}$ (ml/kg, p.o.) } \\
\hline & & & 0.2 & 1.0 & 2.0 \\
\hline GOT & K.U. & $85 \pm 3$ & $84 \pm 12$ & $900 \pm 618 * *$ & $3013 \pm 671 * *$ \\
\hline GOT & K.U. & $20 \pm 2$ & $22 \pm 3$ & $529 \pm 377 * *$ & $1712 \pm 310 * *$ \\
\hline $\mathrm{TC}$ & $\mathrm{mg} / \mathrm{dl}$ & $75.9 \pm 13.7$ & $62.9 \pm 14.0$ & $49.4 \pm 5.9 * *$ & $67.5 \pm 18.3$ \\
\hline PL & $\mathrm{mg} / \mathrm{dl}$ & $92.8 \pm 12.6$ & $87.0 \pm 16.4$ & $67.2+9.1 * *$ & $93.2 \pm 26.5$ \\
\hline TG & $\mathrm{mg} / \mathrm{dl}$ & $43.5 \pm 5.0$ & $32.8 \pm 11.1$ & $14.8+7.5 * *$ & $61.6 \pm 42.1$ \\
\hline TP & $\mathrm{g} / \mathrm{dl}$ & $5.1 \pm 0.2$ & $5.3=0.2 *$ & $5.5 \pm 0.2 * *$ & $5.6 \pm 0.4 *$ \\
\hline
\end{tabular}

Each value represents mean \pm S.D. $*: \mathrm{p}<0.05, * *: \mathrm{p}<0.01$, significantly different from contrcl.

content of the HDL fraction (Tables 1 and 2). After $\mathrm{CCl}_{4}$ administered at $1.0 \mathrm{ml} / \mathrm{kg}, \mathrm{PL}$ contents decreased significantly in serum and VLDL+LDL fraction. In contrast, administration of $2.0 \mathrm{ml} / \mathrm{kg} \mathrm{CCl} \mathrm{Cl}_{4}$ produced $\mathrm{TC}$ and $\mathrm{PL}$ contents in the serum comparable to control levels. The TG content of VLDL+LDL and HDL fractions was decreased by administration of $0.2 \mathrm{ml} / \mathrm{kg} \mathrm{CCl}_{4}$. This decline became greater after administration of $1.0 \mathrm{ml} / \mathrm{kg} \mathrm{CCl}_{4}$. Administration at $2.0 \mathrm{ml} / \mathrm{kg} \mathrm{CCl}_{4}$ tended to increase the TG contents of every fraction, but not significantly. All three doses of $\mathrm{CCl}_{4}$ increased serum TP levels. The protein content of VLDL+LDL fraction was significantly decreased by $1.0 \mathrm{ml} / \mathrm{kg} \mathrm{CCl}$, while at $2.0 \mathrm{ml} / \mathrm{kg}$ $\mathrm{CCl}_{1}$ did not cause significant change. Administrations of $\mathrm{CCl}_{4}$ markedly decreased the pro- 
Table 2. Changes in lipid and protein contents of VLDL + LDL and HDL fractions in $\mathrm{CCl}_{4}$-liver-damage rats.

\begin{tabular}{|c|c|c|c|c|c|c|}
\hline & \multirow{2}{*}{+} & & Control & \multicolumn{3}{|c|}{ Doses of $\mathrm{CCl}_{4}(\mathrm{ml} / \mathrm{kg}$, p.o. $)$} \\
\hline & & & & 0.2 & 1.0 & 2.0 \\
\hline $\mathrm{TC}$ & $\mathrm{mg} / \mathrm{dl}$ & $\begin{array}{c}\mathrm{V}+\mathrm{L} \\
\mathrm{H}\end{array}$ & $\begin{array}{c}8.2 \pm 0.1 \\
66.4 \pm 14.1\end{array}$ & $\begin{array}{r}5.7 \pm 1.8 \\
52.6 \pm 7.6\end{array}$ & $\begin{array}{c}5.7 \pm 2.8 \\
40.2 \pm 2.9 *\end{array}$ & $\begin{array}{l}30.8 \pm 16.5 \\
42.1 \pm 11.0\end{array}$ \\
\hline PL & $\mathrm{mg} / \mathrm{dl}$ & $\begin{array}{c}V+L \\
H\end{array}$ & $\begin{array}{r}6.6 \pm 0.5 \\
59.4 \pm 7.9\end{array}$ & $\begin{array}{r}4.5 \pm 1.7 \\
57.7 \pm 8.5\end{array}$ & $\begin{aligned} 3.2 & \pm 1.7 * \\
45.8 & \pm 4.3\end{aligned}$ & $\begin{array}{l}20.6+11.2 \\
48.0+11.7\end{array}$ \\
\hline TG & $\mathrm{mg} / \mathrm{dl}$ & $\begin{array}{c}\mathrm{V}+\mathrm{L} \\
\mathrm{H}\end{array}$ & $\begin{array}{r}28.0 \pm 2.0 \\
5.6 \pm 0.6\end{array}$ & $\begin{array}{r}18.9 \pm 4.3 * \\
3.1 \pm 1.5 *\end{array}$ & $\begin{array}{l}6.5 \pm 2.4 * * \\
1.2 \pm 0.8 * *\end{array}$ & $\begin{array}{c}38.6 \pm 31.3 \\
7.6 \pm 5.4\end{array}$ \\
\hline Protein & $\begin{array}{r}\mathrm{mg} / \mathrm{dl} \\
\mathrm{g} / \mathrm{dl}\end{array}$ & $\begin{array}{c}\mathrm{V}+\mathrm{L} \\
\mathbf{H}\end{array}$ & $\begin{array}{c}9.6 \pm 0.7 \\
2.79 \pm 0.14\end{array}$ & $\begin{array}{c}8.9 \pm 1.0 \\
1.56 \pm 0.07 * *\end{array}$ & $\begin{array}{c}5.4 \pm 1.4 * * \\
1.93 \pm 0.19 * *\end{array}$ & $\begin{array}{l}13.2 \pm 7.8 \\
0.35 \pm 0.02 * *\end{array}$ \\
\hline
\end{tabular}

Each value represents mean \pm S.D. $*: \mathrm{p}<0.05, * *: \mathrm{p}<0.01$, significantly different from control. V+L: VLDL + LDL fraction, H: HDL fraction.

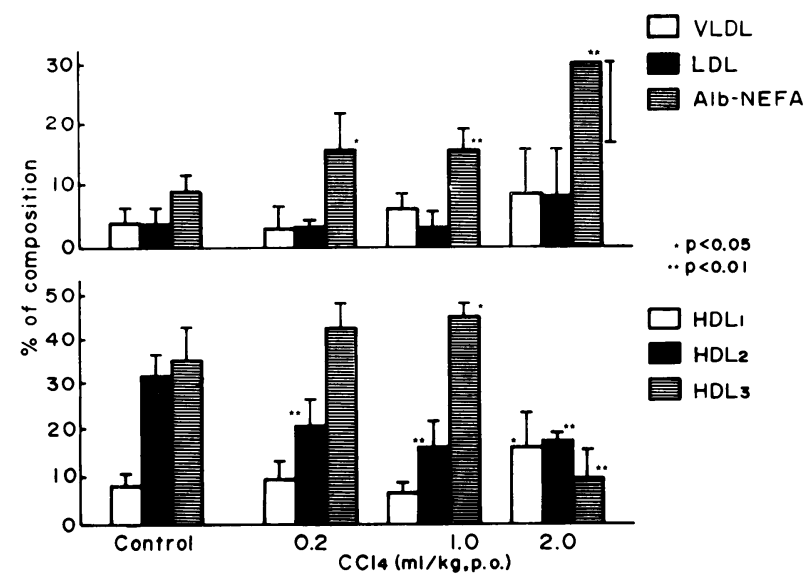

Fig. 2. Effects of $\mathrm{CCl}_{4}$ on rat lipoprotein composition and Alb-NEFA. Each column represents the mean \pm S.D. from 5 or 6 experiments and is expressed as percentage content at each concentration of $\mathrm{CCl}_{4}$. $* \mathrm{p}<0.05$ and $* * \mathrm{p}<0.01$ : Significant differences.

tein content of HDL fraction (Tables 1 and 2).

Changes in lipoprotein population: Densitometrical analysis of polyacrylamide gel disk electrophoresis revealed rat serum lipoprotein migration bands of VLDL (pre beta-lipoprotein), LDL (beta-lipoprotein), $\mathrm{HDL}_{1}, \mathrm{HDL}_{2}, \mathrm{HDL}_{3}$ (alpha-lipoproteins) and Alb-NEFA (Fig. 2). Percentages of VLDL and LDL fractions were not changed by administrations of 0.2 and $1.0 \mathrm{ml} / \mathrm{kg} \mathrm{CCl}_{1}$. Administration of $\mathrm{CCl}_{4}$ at $2.0 \mathrm{ml} / \mathrm{kg}$ slightly increased $\mathrm{VLDL}$ and LDL percentages, but not significantly. The percentage of Alb-NEFA increased significantly after $\mathrm{CCl}_{4}$ treatment at all three doses. Administration of $\mathrm{CCl}_{1}$ decreased $\mathrm{HDL}_{3}$ percentage. Administration of $2.0 \mathrm{ml} / \mathrm{kg} \mathrm{CCl}_{4}$ significantly increased in $\mathrm{HDL}_{1}$ percentage and markedly decreased $\mathrm{HDL}_{2}$ and $\mathrm{HDL}_{3}$ (Fig. 2).

Changes in apoprotein contents of HDL fraction: Changes in HDL apoproteins are 


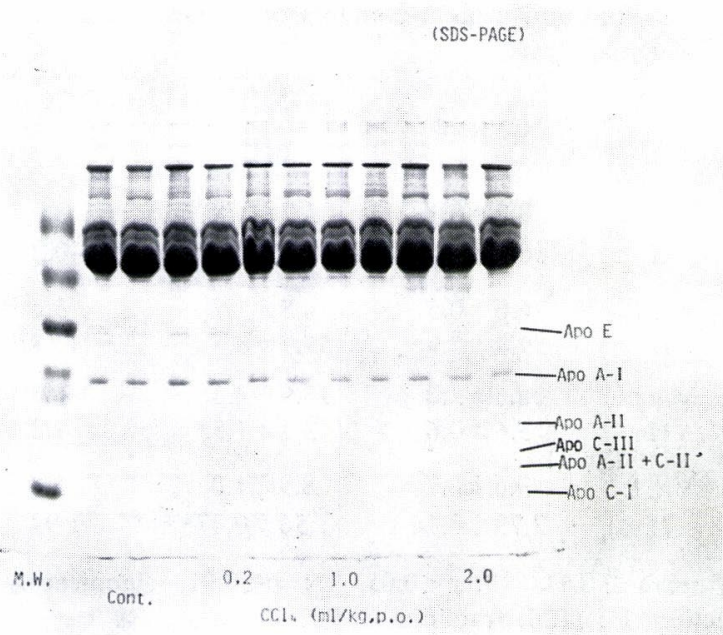

Fig. 3. Effects of $\mathrm{CCl}_{4}$ on SDS-PAGE patterns of rat apoproteins. M.W.: molecular weight marker gave stained bands of cytochrome c's (numbers in parenthesis are molecular weights, the order is from the bottom): monomer (12300), dimer (24600), trimer (36900), tetramer (49200), pentamer (61500), and hexamer (73800).

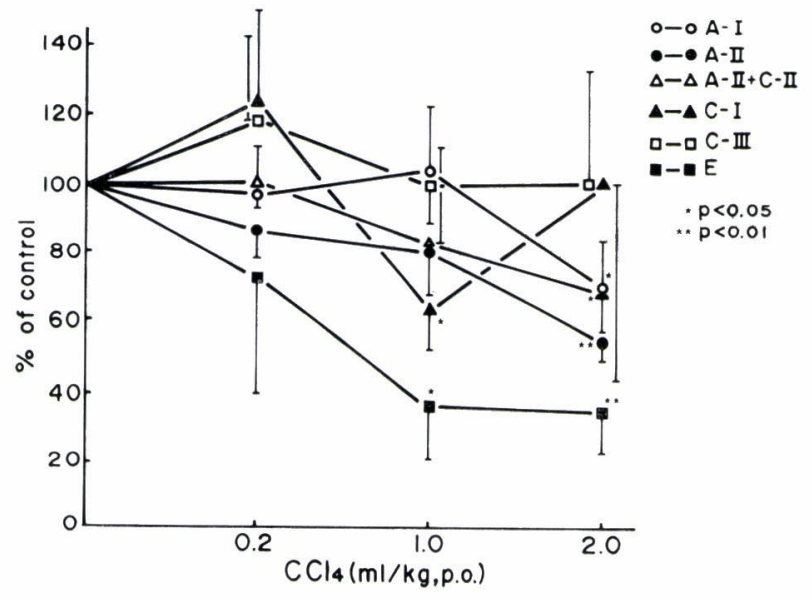

Fig. 4. Effects of $\mathrm{CCl}_{4}$ on rat HDL apoproteins. Each point represents the mean \pm S.D. of densitometrical analysis in SDS-PAGE from 3 experiments. Each value is expressed as a percentage of the control. $* \mathrm{p}<0.05$ and $* * \mathrm{p}<0.01$ : Significant differences.

shown in Fig. 3. The stained bands of cytochrome $\mathrm{c}$ mixture, a molecular weight marker for SDS-PAGE, were in order from the bottom: figures in parenthesis are molecular weight: monomer (12300), dimer (24600), trimer (36900), tetramer (49200), pentamer (61500), and hexamer (73800) (Fig. 3).

Changes in HDL apoproteins were measured with densitometry of the electrophoretic bands and expressed as percentages of control values in Fig. 4. Apo C-I and apo E significantly decreased with administration of $1.0 \mathrm{ml} / \mathrm{kg} \mathrm{CCl}_{1}$. Significant declines of apo A-I, apo 


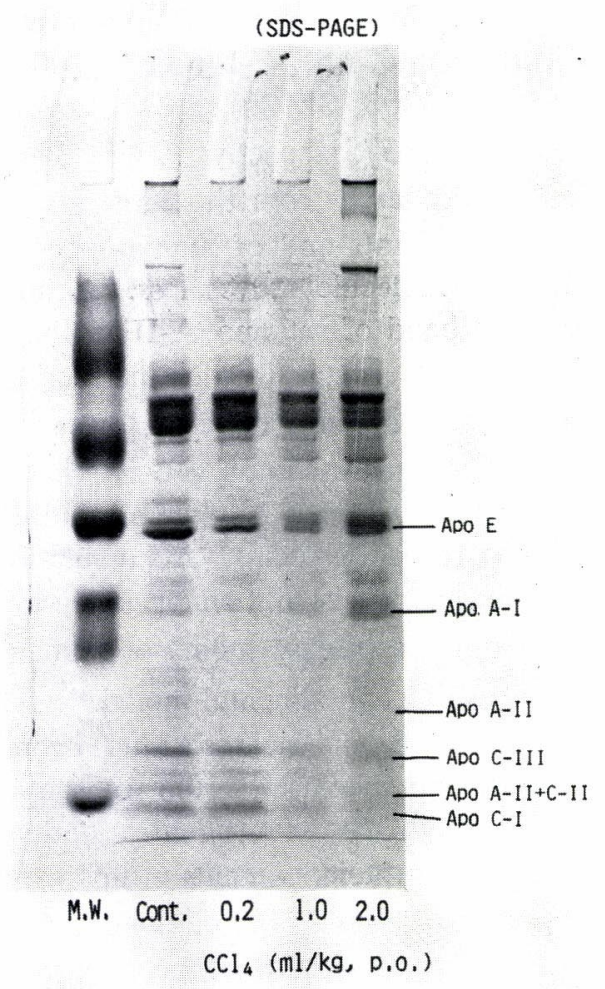

Fig. 5. Effects of $\mathrm{CCl}_{4}$ on SDS-PAGE patterns of rat VLDL and LDL apoproteins. Other explanations as for Fig. 4.

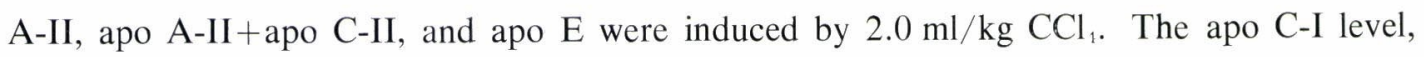
at $2.0 \mathrm{ml} / \mathrm{kg}$, was similar to the control level, although the value at $2.0 \mathrm{ml} / \mathrm{kg}$ had a large standard deviation.

Changes in VLDL+LDL apoproteins: Electrophoretic patterns of VLDL+LDL apoproteins separated by SDS-PAGE are shown in Fig. 5. A control electrophoretic pattern showed clearly stained bands of apo A-I, apo C-I, apo A-II+C-II, apo C-III and apo E. Administrations of 0.2 and $1.0 \mathrm{ml} / \mathrm{kg} \mathrm{CCl}_{4}$ weakened the apo A-I, apo A-II $+\mathrm{C}-\mathrm{II}$ and apo $\mathrm{E}$ of bands. Administration of $2.0 \mathrm{ml} / \mathrm{kg} \mathrm{CCl}$ induced an increase in apo $\mathrm{C}-\mathrm{I}$, and decreases in apo A-I, apo A-II+C-II, and apo E.

Apo $\mathrm{B}$, which is not water soluble and has a high molecular weight, does not migrate in the gel employed in this study. Therefore, densitometrical analysis of apo B could not be performed. When VLDL+LDL apoprotein contents were expressed in comparison with the control value, all apoproteins except apo $\mathrm{C}$ - $\mathrm{I}$ tended to decrease after $\mathrm{CCl}_{4}$ treatments at all three doses. Administration of $2.0 \mathrm{ml} / \mathrm{kg} \mathrm{CCl}{ }_{1}$ produced an apo C-I level comparable to the control level.

\section{Discussion}

Our results demonstrated that rat apoprotein patterns in HDL fraction produced in SDSPAGE were similar to those of humans since the migration distances were almost the same. 
The respective molecular weights of human and rat apoproteins are as follows: apo A-I (28300, 27000), apo A-II $(8690,8000)$, apo C-I $(6631,7000))$ apo C-II $(8837,8000)$, apo C-III $(8764,10000)$, apo $\mathrm{E}(34000,35000) .{ }^{20)}$ The anhydrous molecular weights of apo C-I and apo C-III are 6631 and 8837 , respectively. ${ }^{2122)}$ The migration ranges of human apo A-II+apo C-II and apo C-III differed from those of rats. The difference between the molecular weights of these proteins of rats and of man might account for the difference in migration distances since a heavier molecule moves less. Although rat apo A-II had been thought to exist as a monomer, the band of rat apo A-II in the present study migrated the same distance as the human apo A-II, which is identified as a dimer (molecular weight 17414). ${ }^{20)}$ Thus, from our data we could not deny the possibility that rat apo A-II may be present in a dimeric form. The present study proved that SDS-PAGE and isoelectric focusing, the methods generally employed for human apoprotein determination, could be adapted for the determination of rat apoproteins. Accumulation of detailed data on apoproteins in animals, i.e., their normal levels and changes due to $\mathrm{CCl}_{4}$-induced liver damage, should be indispensable for developing a disease model of human hepatic disorder.

$\mathrm{CCl}_{1}$-induced liver injury is a useful experimental model. ${ }^{23)}$ Subcutaneous injection of 1.0 $\mathrm{ml} / \mathrm{kg} \mathrm{CCl}_{4}$ is supposed to trigger centrizonal steatosis and necrosis in the liver. ${ }^{24}$ It decreases serum lipid and TP levels, and increases serum transaminases. In the present study, $\mathrm{CCl}$. treatment induced liver damage dose-dependently, and increased remarkably serum transaminase activity. The lipid and protein contents of lipoprotein fractions were decreased from the control level at the lower two doses of $0.2 \mathrm{ml} / \mathrm{kg}$ and $1.0 \mathrm{ml} / \mathrm{kg}$, and were comparable to the control level at the highest dose, $2.0 \mathrm{ml} / \mathrm{kg}$. This might reflect the process of necrosis in the liver.

$\mathrm{CCl}_{4}$ increased Alb-NEFA and decreased $\mathrm{HDL}_{2}$ observed in electrophoretic analysis of serum lipoproteins. The increase in Alb-NEFA may reflect an increase in the amount of release of TG decomposition products from the liver, where TG accumulated. The decrease in $\mathrm{HDL}_{2}$ percentage indicates inhibition of the conversion of $\mathrm{HDL}_{3}$ to $\mathrm{HDL}_{2}$. Especially, the decrease in apo $\mathrm{E}$ content of the HDL fraction by $\mathrm{CCl}_{1}$ administrations at $0.2 \mathrm{ml} / \mathrm{kg}$ and $1.0 \mathrm{ml} / \mathrm{kg}$ correlated with the decrease in conversion from $\mathrm{HDL}_{3}$ to $\mathrm{HDL}_{2}$. Felker et al. reported that apo $\mathrm{E}$ was a major protein component of both VLDL and HDL in rat liver perfusates. ${ }^{25)}$ The apo E content of $\mathrm{HDL}_{3}$ may control the conversion. Furthermore, the decline of the $\mathrm{HDL}_{3}$ percentage induced by $2.0 \mathrm{ml} / \mathrm{kg} \mathrm{CCl}$, suggests inhibition of $\mathrm{HDL}_{3}$ synthesis. The decreases of apo A-I, apo A-II, apo A-II+apo C-II, and apo E contents of the $\mathrm{HDL}$ fraction by $2.0 \mathrm{ml} / \mathrm{kg} \mathrm{CCl}_{1}$ correlated with the decreases of protein and lipid contents of the HDL fraction. These decreases also indicate suppression of apoprotein synthesis in the liver. In the VLDL+LDL fraction, the administration of $\mathrm{CCl}_{1}$ at $2.0 \mathrm{ml} / \mathrm{kg}$ increased lipids and apoproteins which had been decreased by $1.0 \mathrm{ml} / \mathrm{kg}$ of $\mathrm{CCl}_{1}$. This might reflect VLDL+LDL metabolism alterations, such as reduction of lipoprotein lipase activity in serum due to the decrease of apo C-II.

Galactosamine induces diffusing hepatocellular injury which closely resembles human hepatitis. Galactosamine is widely used to produce an experimental liver damage model, ${ }^{26)}$ but its injury form and resulting changes in serum lipid levels differ from those induced by $\mathrm{CCl}_{1}$. Sirowej et al. ${ }^{10)}$ reported that apo A-II and apo C's in VLDL and HDL diminished with galactosamine treatment. Cartwright et al. ${ }^{2 i)}$ also reported that galactosamine-induced hepatitis in rats was associated with various alterations in plasma; increased contents of unesteri- 
fied cholesterol, PL, and TG, severe deficiency of lecithin-cholesterol acyl transferase (LCAT), and the appearance of discoidal lipoproteins. In addition, decline of apo C-III in the VLDL fraction, and increase of apo $\mathrm{E}$ as well as decrease of apo C's in the HDL fraction were triggered by galactosamine treatment. Investigators who employed lower doses of galactosamine detected no changes in apo A-I or apo E content of the HDL fraction after galactosamine treatment.

In the present study, we demonstrated that apoprotein changes in $\mathrm{CCl}_{4}$-induced liver injury differed from those in galactosamine-induced liver injury. Administration of $1.0 \mathrm{ml} / \mathrm{kg}$ $\mathrm{CCl}_{4}$ decreased the apo E content of the HDL fraction, which was opposite to the effect of galactosamine treatment. $\mathrm{HDL}_{1}$, an apo E-rich $\mathrm{HDL}$ fraction, proved to be a better LCAT substrate than any other HDL fraction in serum. Lipoprotein abnormalities in the galactosamine-induced LCAT deficiency, familial LCAT deficiency, and patients with liver disease, emphasize the central role of LCAT in plasma lipoprotein metabolism. ${ }^{10)} \mathrm{CCl}_{4}$ treatment suppressed protein synthesis, decreased protein content in HDL fractions and reduced $\mathrm{HDL}_{2}$ percentages. Especially, the decline of $\mathrm{HDL}_{3}$ percentage upon administration of $2.0 \mathrm{ml} / \mathrm{kg}$ $\mathrm{CCl}_{4}$ might be caused by the inhibition of LCAT activity and the decrease of Apo A-I level.

In summary, our data suggest that lipoprotein abnormalities induced by $\mathrm{CCl}_{4}$ may be related to inhibition of apoprotein synthesis, suppression of lipoprotein lipase activity, and the decline of $\mathrm{HDL}_{2}$ percentage. Also, our data revealed differences between changes due to $\mathrm{CCl}_{4}$ - and galactosamine-induced liver injuries in rat. The understanding of such detailed differences in experimental animals will be important in developing an appropriate disease model of human hepatic disorder.

\section{References}

1) Avogaro P, Bon GB, Cazzolato G and Rorai E: Relationship between apolipoproteins and chemical components of lipoproteins in survivors of myocardial infarction. Atherosclerosis, 37: 69-76 (1980)

2) Berge KG, Canner PL and Hainline A: High-density lipoprotein cholesterol and prognosis after myocardial infarction. Circulation, 66: 1176-1178 (1982)

3) Swaney JB, Reese H and Eder HA: Polypeptide composition of rat high density lipoprotein: Characterization by SDS-gel electrophoresis. Biochem Biophys Res Commun, 59: 513-519 (1974)

4) Weidman SW, Suarez B, Falko JM, Witztum JC, Kolar J, Raben M and Schonfeld G: Type III hyperlipoproteinemia: development of a VLDL apo E gel isoelectric focusing technique and application in family studies. J Lab Clin Med, 93: 546-569 (1979)

5) Rosseneu M, Van Tornout P, Lievens MJ and Assmann G: Displacement of the human apoprotein A-I by the human apoprotein A-II from complexes of (apoprotein A-I)-phosphatidylcholine-cholesterol. Eur J Biochem, 117: 347-352 (1981)

6) Kane JP, Sata T, Hamilton RL and Havel RJ: Apoprotein composition of very low density lipoproteins of human serum. J Clin Invest, 56: 1622-1634 (1975)

7) Ragland JB, Heppner C and Sabesin SM: The role of LCAT deficiency in the apoprotein metabolism of alcoholic hepatitis. Scand J Clin Lab Invest, 38: 208-213 (1978)

8) Mitchell CD, King WC, Applegate KR, Forte T, Glomset JA, Norum KK and Gjone E: Characterization of apolipoprotein E-rich high density lipoproteins in familial lecithin: cholesterol acyltransferase deficiency. J Lipid Res, 21: 625-634 (1980)

9) Koga S, Bolis L and Scanu AM: Isolation and characterization of subunit polypeptides from apoproteins of rat serum lipoprotein. Biochim Biophys Acta, 236: 416-430 (1971)

10) Sirowej H, Assmann G and Katterman R: Lipoproteins and apoprotein patterns in rat plasma after liver injury induced by D-galactosamine. Hoppe-Seylers Z Physiol Chem, 361: 1417-1425 (1980)

11) Maruyama $\mathbf{M}$ and Kobori U: Investigations of disk electrophoretic condition in serum lipoproteins. Phys-Chem Biol, 16: 243-245 (1972) (in Japanese)

12) Weber $K$ and Osborn $M$ : The reliability of molecular weight determinations by dodecylsulfate- 
polyacrylamide gel electrophoresis. J Biol Chem, 244: 4406-4412 (1969)

13) Schaefer EJ, Eisenberg S and Levy RI: Lipoprotein apoprotein metabolism. J Lipid Res, 19: 667-687 (1978)

14) Zlatkis A and Zak B: Study of a new cholesterol reagent. Anal Biochem, 29: 143-148 (1969)

15) Takayama $M$, Itoh $S$, Nagasaki $T$ and Tanimizu $I$ : A new enzymatic method for determination of serum choline-containing phospholipids. Clin Chim Acta, 79: 93-98 (1977)

16) Bucolo $G$ and David H: Quantitative determination of serum triglycerides by the use of enzymes. Clin Chem, 19: 476-482 (1973)

17) Ohkawa J, Miyoshi Y, Matsuura S and Misaki H: A new colorimetric method for the determination of transaminase activity using pyruvate oxidase. Jpn J Clin Pathol, 26 (Suppl): 70 (1978) (in Japanese )

18) Weichselbaum TE: An accurate and rapid method for the determination of proteins in small amounts of blood serum and plasma. Am J Clin Pathol, 16: 40-49 (1946)

19) Bradford MM: A rapid and sensitive method for the quantitation of microgram quantities of protein utilizing the principle of protein-dye binding. Anal Biochem, 72: 248-254 (1976)

20) Mahley RW, Innerarity TL, Rall SC and Weisgraber KH: Plasma lipoprotein structure and fraction. J Lipid Res, 25: 1277-1294 (1984)

21) Shulman RS, Herbert PN, Wehrly K and Freadrickson DS: The complete amino acid sequence of C-I (apo LP-SER), an apolipoprotein from human very low density lipoproteins. J Biol Chem, 250: 182-190 (1975)

22) Brewer HB, Shulman R, Herbert P, Ronan DM and Wehrly K: The complete amino acid sequence of an apolipoprotein obtained from human very low density lipoprotein (VLDL). Adv Exp Med Biol, 26: 280 (1972)

23) Nakayama S, Okazaki M, Sakai S, Nakamura $Y$ and Sakamoto K: Pharmacological studies of diisopropyl 1,3-dithol-2-ylidene malonate (NKK-105) report 4; Effects of $\mathrm{NKK}-105$ on $\mathrm{CCl}_{4}$-induced fatty liver in rats. J Showa Med Assoc, 39: 19-28 (1979) (in Japanese)

24) Nakayama S, Gotoh H, Oguchi E, Okazaki M and Sakamoto K: Effect of diisopropil 1,3-dithol2-ylidene malotinate (Malotilate) on $\mathrm{CCl}_{4}$-induced liver damage in rats. J Showa Med Assoc, 42: 605-611 (1982) (in Japanese)

25) Felker TE, Fainaru M, Hamilton RL and Havel RJ: Secretion of the arginine-rich and apoproteins by the isolated perfused rat liver. J Lipid Res, 18: 465-473 (1977)

26) Sabein SM, Kuiken LB and Ragland JB: Lipoprotein and LCAT changes in galactosamine-induced rat liver injury. Science, 190: 1302-1304 (1975)

27) Cartwright CK, Ragland JB, Weidman SW and Sabesin SM: Alterations in lipoprotein composition associated with galactosamine-induced rat liver injury. J Lipid Res, 23: 667-679 (1982)

[Received August 22, 1989: Accepted October 11, 1989] 